ОЛЕКСАНДРА ЦИБАНЮК, кандидат педагогічних наук, дочент кафедри теорії та методики фізичного виховання і спорту, Чернівецький начіональний університет імені Юрія Федьковича, Украӥна ORCID 0000-0001-5367-5747 o.tsibanyuk@chnu.edu/ua

\title{
ІННОВАЦІЙНИЙ ПІДХІД ДО ПРОГРАМОВОГО ЗАБЕЗПЕЧЕННЯ ФІЗИЧНОГО ВИХОВАННЯ УЧНІВ ПОЧАТКОВОЇ ШКОЛИ РУМУНІЇ (2014-2020 роки)
}

OLEKSANDRA TSYBANUYK, PhD (pedagogics), Assoc. Prof., dept. of theory and methodology of Physical Education and sport, Yuriy Fedkovych Chernsvtsi National University, Ukraine

\section{INNOVATIVE APPROACH TO THE PROGRAM OF PHYSICAL EDUCATION OF PRIMARY SCHOOLCHILDRENS OF ROMANIA (2014-2020)}

У статті проаналізовано особливості програмового забезпечення фізичного виховання школярів румунської початкової школи, наявність двох навчальних предметів - "Фізичне виховання" та "Гра і рух" в початковій ланці освіти Румунії. Визначено основні положення навчальних програм. Автор наголосив, що саме такий синтез напряму впливає на конкретне навчання щодо формування здоров'я учнів шляхом виховання потреби в русі. На його думку, програма "Гра і рух" забезпечує обов'язковий обсяг фізичної активності школярів початкових класів.

Ключові слова: вправи, гра, навантаження, початкова школа, програма, Румунія, фізичне виховання, форми.

Summary. The article analyzes the features of the program of physical education of Romanian primary school students? the presence of two subjects ? "Physical Education" and "Game and Movement" in primary education in Romania and identified the main provisions of the curriculum. The author emphasized that such a synthesis directly affects the specific training in shaping the health of students by educating the need for movement. In his opinion, "Game and Movement" provides a mandatory amount of physical activity for elementary

() О. Цибанюк schoolchildrens.

Key words: exercises, game, load, elementary school, program, Romania, physical education, forms.

Мета: проаналізувати зміст інноваційної шкільної програми для 3-4 класів початкової школи сучасної Румунії "Гра і рух".

Постановка проблеми в загальному вигляді. Модернізація українського соціуму постає як практична потреба сучасного етапу державотворення, як завдання конкурентоспроможного входження до європейського і світового соціокультурного простору, утвердження в ньому як привабливого, перспективного, прогнозованого, а тому й надійного партнера. Громадська думка та соціальна практика здебільшого ігнорують можливості фізичної культури і спорту у вирішенні багатьох важливих соціально-економічних проблем. Проте для всіх освітян і фахівців галузі стає очевидним, що актуальною нині є потреба глибокого реформування фізкультурної освіти та фізичного виховання підростаючого покоління відповідно до національно-ідейних цінностей та світової динаміки. У цьому сенсі актуальним постає питання вивчення теорії і практики фізкультурної освіти у країнах Свропейського Союзу, оскільки наукове обгрунтування подібної проблематики диктується сучасними тенденціями оптимізації або навіть реформування освітнього процесу. Фізкультурна освіта та фізичне виховання повинні відбуватися 3 урахуванням і на основі державних особливостей розвитку культури і спорту, що є системою орієнтирів і поглядів на роль, організацію і функціонування сфери зазначеної вище галузі на довгостроковий період з урахуванням розвитку держави та світового досвіду.

Аналіз досліджень і публікацій. Вивчення досвіду європейських країн у галузі фізичного виховання і спорту представлено низкою праць педагогів, фахівців галузі тощо. Зокрема, проблемам моніторингу фізичного виховання школярів присвячені дослідження Я. Галана, Т. Завгородньої, М. Кожокар, І. Стражнікової (Tsybanyuk O., Galan $Y$., Yarmak O., Kyselytsia O., Paliichuk Y., 2018; Tsybanyuk O., Galan Y., Zavgorodnia T., Strazhnikova I., Kushnir I., Shestobuz O., Yarmak O., Kozhokar M., 2019).

Аспекти реформування фізичного виховання в постсоціалістичних країнах вивчали Г. Арделян, Г. Богданов, А. Карпов, З. Кузнецов, О. Куц. Проблеми фізичного виховання в Румунії, а саме методика проведення занять у загальноосвітніх школах та ліцеях соціалістичного часу вивчав I. Попеску.

Виклад основного матеріалу дослідження. Для реалізації мети нашої праці використано певний комплекс 
методів: загальнонаукові (аналіз, синтез, порівняння, узагальнення, систематизація) - для обгрунтування актуальності дослідження, визначення понятійно-категоріального апарату, формулювання висновків; конкретно-наукові (теоретичний аналіз архівних документів, періодичних видань, історико-педагогічної літератури, методичних та програмових матеріалів) - для систематизації та класифікації історико-педагогічної, методичної літератури; конкретно-історичний - для визначення змісту, методів і форм фізичного виховання за вимогами шкільної програми для 3-4 класів початкової школи "Гра і рух"; проблемно-хронологічний - для з'ясування трансформації та розвитку змісту фізичного виховання в сучасній румунській школі. Вибір комплексу означених методів забезпечує логічність і цілісність наукового дослідження, дає можливість структурувати, порівнювати дані процеси в їхній динаміці, визначати й обгрунтовувати практичну значущість результатів дослідження.

Згідно 3 нормативно-правовою базою Румунії та програмовим забезпеченням навчання у школі сфера "Фізичне виховання, спорт і здоров'я" охоплює два навчальні предмети для початкової школи - "Фізичне виховання" та "Гра і рух". Саме такий синтез напряму впливає на конкретне навчання щодо формування здоров'я учнів шляхом виховання потреби в русі. Предмет "Фізичне виховання" безпосередньо забезпечує фізичний розвиток, який реалізується через формування рухливих умінь і навичок, зростання фізичних якостей, надання переваги інтеграції у природне та соціальне середовище.

Навчальний предмет "Гра і рухи" має завданням доповнювати та підсилювати цей вплив, упроваджуючи ігри з їх пізнавальною, соціальною і розвивальною складовою.

Предмет "Фізичне виховання" вивчається відповідно до програми дві години на тиждень учителем фізичного виховання, а для "Гри і руху" передбачена одна година на тиждень під керівництвом учителів початкових класів або фахових інструктора чи вчителя (Programa scolara pentru disciplina "Educatie fizica", 2014).

Положення програми 3-4 класів розроблені за новою моделлю шкільного проєктування, концентрованої на компетенціях. Наповнення програм скомпоновано таким чином, щоб вони сприяли розвиткові учня 3 початкового етапу навчання, використовуючи знання, уміння i навички, набуті в закладах дошкільної освіти. Основний орієнтир педагогічного курсу, починаючи з компетенцій, мети і відповідно форм і методів - формування особистості учня.

Структура шкільних програм включає такі елементи: вступ, основні компетенції, специфічні компетенції і приклади навчальної діяльності, основний зміст і висновки 3 очікуваними результатами впровадження програм. Згідно з положеннями програм, компетенції- це структурована система знань, навичок і досвіду, сформована шляхом навчання і виховання, що дозволяють досягти максимального результату. Головні компетенції, передбачені в змісті предмета "Фізичне виховання", визначають рівень рухової активності учня, ознайомлення його з необхідними навичками для здорового життя і гармонійного фізичного розвитку. Головні компетенції, передбачені для учнів 3-4 класів, базовані на передбачених у програмі для 1-2 класів (Programa scolars pentru disciplina "Joc si miscare", 2014).

Специфічні компетенції витікають з головних і представляють етапи їх засвоєння упродовж одного шкільного року. Методологічні висновки передбачають визначення педагогічної стратегії та проєктування педагогічного контролю і систематичного оцінювання.

Аналізовані навчальні програми не $\epsilon$ догмою і представляють гнучку пропозицію, яка дозволяє фахівцям варіювати освітню діяльність. Передбачено реалізацію педагогічного персоніфікованого впливу, який забезпечить формування знань, передбачених програмою в контексті, специфічному для кожного класу та кожного учня.

Саме вікова специфіка, основана на мотивації навчатись через ігри, стала базою для диференціації педагогічних дій залежно від рівня фізичної підготовленості дітей. Розглянемо програму "Гра і рух" для 3 і 4 класу румунської школи, що була апробована згідно 3 додатком № 2 до наказу Міністра національної освіти Румунії № 5003/02.12.2014 в 2014 р. та впроваджена в навчально-виховну діяльність шкіл цієї країни у 2019 році (Programa scolara pentru disciplina
"Joc ci miscare", 2014).

Упровадження предмета "Гра і рух" до навчальних планів 3-4 класів румунських шкіл закцентувало роль ігрової діяльності у процесі розвитку дітей віком 9-10/11 років. Як повноцінна й інтегрована складова програмового забезпечення програма "Гра і рух" підкреслює освітній, виховний і навчально-тренувальний потенціал ігор, особливо адресний саме для періоду молодшого шкільного віку.

Велика кількість видів рухливих ігор ( і без предметів) спрямовані на співпрацю і змагання, з ролями чи без них, можуть стати в основі проектування певних ситуацій в навчанні з багатим і корисним впливом на особистість дитини.

Потенціал рухливих ігор може бути використаний для зміцнення знань, отриманих під час вивчення інших предметів (румунська мова, математика, природознавство тощо). Інтегрований спосіб засвоєння цих предметів робить можливим вивчання/зміцнення абетки, цифр, назви тварин, фруктів, овочів тощо. Внаслідок специфіки групової діяльності, рухлива гра сприяє демонстрації соціальних взаємин (кооперування, змагання), передбачаючи гармонізацію індивідуальних інтересів і власних зусиль 3 груповими; сприяє входженню в колектив, взяття на себе відповідальності, демонстрування критичної і самокритичної поведінки, ініціативи та дозволяє дітям з'ясувати, що означають толерантність, сприйняття іншого, прийняття рішення і відповідальність за його наслідки.

Гра передбачає дотримання правил, тому навчальний предмет "Гра і рух" сприяє моральному розвитку дитини, дозволяє здійснити його шкільну та соціальну інтеграцію. Унаслідок позитивних або негативних ситуацій, з якими стикається учень у процесі гри, переживатиме широкий спектр різних почуттів: радість, сум, вдячність, ентузіазм, задоволення. Він має нагоду пізнавати ці стани, зрозуміти їх і навчитися контролювати для того, аби мати урівноважену поведінку у школі і суспільстві.

Шкільна програма з курсу "Гра і рух" пропонує гнучке започаткування, засноване на оцінці компетенцій і досвіді вчителя, специфічних ресурсів закладу освіти. Педагогічні кадри вільні вибирати, змінювати або доповнювати освітню діяльність, яка має бути пристосована до особливостей учнів та базуватися на навчанні 
через ігри. У свою чергу, учні заохочені висловлювати свої враження щодо впровадження у процес навчання певних ігор. Серед основних компетенцій програма називає:

- участь у рухливих іграх, організованих або спонтанних;

- демонстрацію адекватної соціальної поведінки у щоденній діяльності.

Відповідно у програмі розділені специфічні компетенції і представлені приклади навчальної діяльності. Їх розподіл стосовно першої основної компетенції представлено в таблиці 1.1 .

Друга специфічна компетенція, що визначає демонстрацію адекватної соціальної поведінки в повсякденній діяльності, диференційована для третіх класів таким чином. У процесі вивчення предмета учні повинні навчитись управляти груповими i міжгруповими взаєминами у грі. А для цього необхідно виконувати певні спільні завдання під час гри, брати активну участь у діях групи, зокрема, в уникненні/посередництві конфліктів.

У контексті ігрової діяльності важ- ливим визначено врівноважене сприйняття перемоги/поразки в рухливих іграх. Тому у програмі закладено:

- виконання ролей і завдань у команді (капітан команди, суддя, секретар тощо);

- участь у жеребкуванні;

- вітання членів команди/суперників;

• самостійний аналіз власної результативності та результативності команди.

Упровадження цієї компетенції до виховного процесу сучасної початкової освіти є необхідним для повноцінного розвитку дитини шкільного віку, формування у неї здібностей та можливостей, необхідних для самостійного розв'язання різних життєвих проблем; здатної до співпереживання; готової до вільного гуманістично орієнтованого вибору, індивідуального інтелектуального зусилля і самостійної, компетентної та відповідальної дії в політичному, економічному, професійному і культурному житті; яка поважає себе й інших; терпима до представників інших національностей; незалежна в думках та відкрита для іншого погляду й несподіваної думки (Гушлєвська, 2004, с. 22-24.).

Складові другої специфічної компетенції за програмою "Гра і рух" та приклади навчальної діяльності запропоновані лише для четвертого класу представлені в таблиці 1.2.

Основний зміст програми презентує перелік видів рухливих ігор і естафет, диференційований відповідно для третіх і четвертих класів. Наведемо їх перелік для третього класу згідно з програмою "Гра і рух". Ігри розділяються на три великі групи. Перша група (ігри для розвитку психомоторики) об'єднала: а) рухливі ігри з різновидами ходьби, носінням предметів (наприклад, "Вимірювачі"); б) рухливі ігри й естафети із різновидами бігу: зіг-заг, з оббіганням перешкод, 3 перенесенням предметів ("Кучер і кінь", "Трійка", "Полювання", "Горобець і бджола", "Миша і кіт", "Пошта йде"); в) ігри й естафети зі стрибками ("Еластична резинка", "Бережи ноги"); г) ігри й естафети 3 киданням і пійманням: кидання двома руками вперед, угору і над головою, піймання однією рукою, метан-

\section{Табличя 1.1}

Участь в рухливих іграх залежно від психомоторних можливостей та індивідуаль них

\section{інтересів школярів}

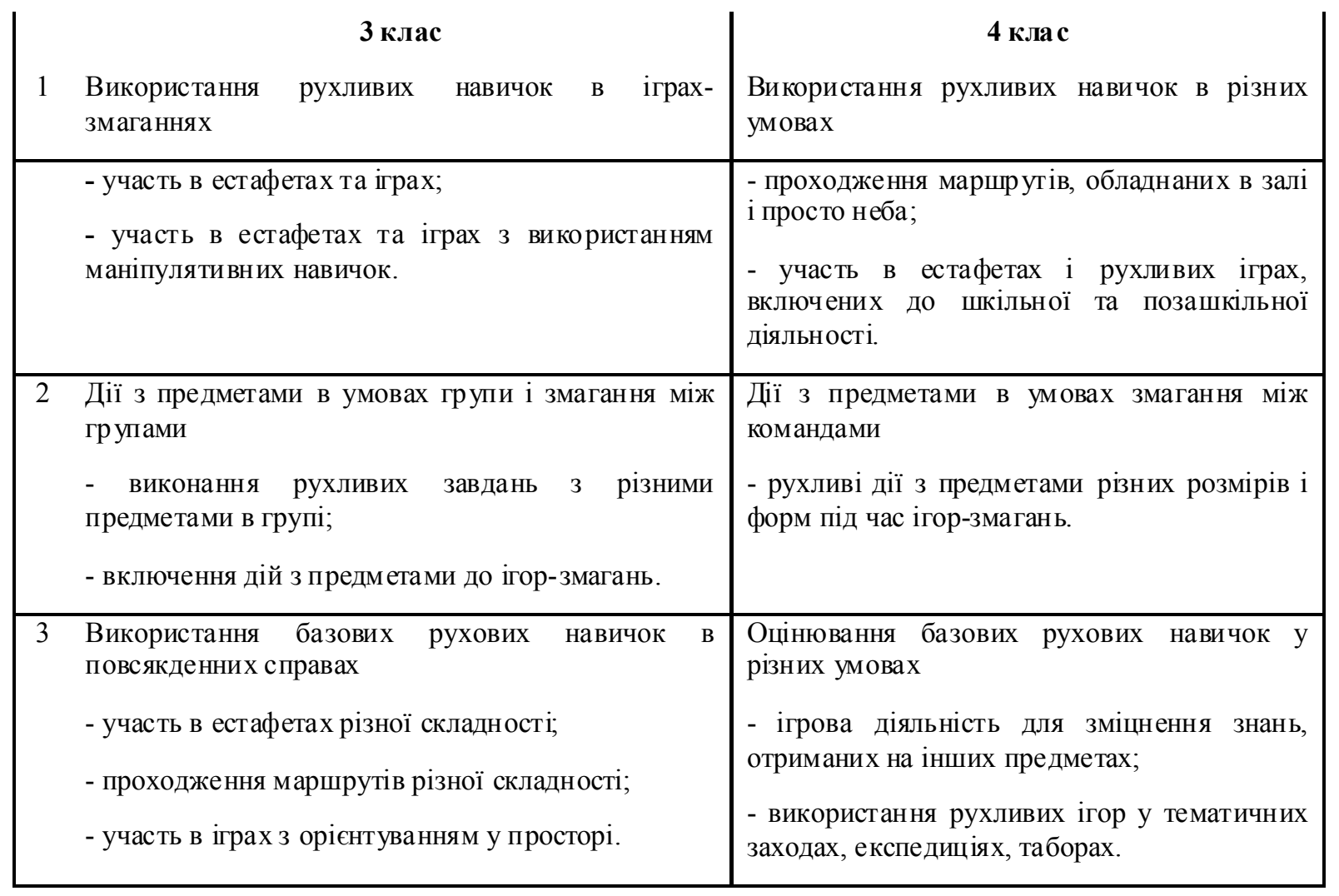


Таблиия 1.2

Складові другої специфічної компетенції за програмою «Гра і рух» та приклади навчаль ної діяльності для 4 класу

\begin{tabular}{|c|c|}
\hline $\begin{array}{l}\text { Складові компетенції } \\
\text { Взяття на себе відповідальності у } \\
\text { виконанні індивідуальних ролей у } \\
\text { межах групи, в грі. }\end{array}$ & $\begin{array}{l}\text { Приклади діяльності } \\
\text { - адекватне } \\
\text { керівника/підпорядкованого; } \\
\text { - участь у розподілі ролей; } \\
\text { - участь у створені команди. }\end{array}$ \\
\hline $\begin{array}{l}\text { Організація й адаптація рухливих } \\
\text { ігор у повсякденній шкільній і } \\
\text { позашкільній діяльності. }\end{array}$ & $\begin{array}{l}\text { - організація рухливих ігор з різними правилами, } \\
\text { різної ефективності і в різних умовах; } \\
\text { - адаптація засвоєних ігор до позашкільної } \\
\text { діяльності; } \\
\text { - визнання поразки і прагнення реваншу. }\end{array}$ \\
\hline
\end{tabular}

ня на дальність і в ціль ("Подвійний човник", "Мисливці й качки", "Вівчар", "Досвідчені стрільці"); д) ігри, переходи й естафети, що включають складні рухливі навички: тягнення-штовхання, лазання-сходження ("Коток", "Гірка для катання", "Літак"); з) рухливі ігри й естафети, які передбачають розвиток рухових якостей; к) ігри для орієнтації у просторі i часі.

Друга велика група об'єднує: а) ігри та вправи, які виховують навички спілкування та співпраці у групі: ефективні техніки спілкування під час рухливих ігор (наприклад: жести, сигнали, знаки); б) вправи задля засвоєння ролей (для прикладу, дії у парах, малих групах, зі зміною ролі у процесі кожної дії); в) ігри-опитування задля вислуховування і погодження 3 думками інших (наприклад, запитання і відповіді щодо результатів ігор); г) ігри-наслідування (нагляд за дотриманням правил і порядку під час проведення ігор); д) ігри з ознайомлення із правилами взаємодії між групами: повага до команди суперників, визнання результатів змагання під час ігор, нагляд за дотриманням правил партнерами змагань ("Взяття на буксир", "Швартування судна до берега", "Між двома вогнями" тощо).

Третя група ігор має назву "Активний стиль життя". Вона комбінує різноманітні ігри і спортивно-масові заходи, дитячий туризм, наприклад: рухливі ігри для розвитку серцевої і дихальної систем ("Яструб і голуб", "Невід", "Доганялки"); ігри, що проводяться в різні пори року під відкритим небом ("Коток або Сніжна гора", "Візники", "Досвідчені стрільці", "Ра- хівниці", "Мисливці і качки", "Вівчар оберігає вівці", "М'яч у капітана"). Крім того, сюди віднесено рухову активність у вільний час, на екскурсіях, утаборах, походах, а також шкільні конкурси у школах, між школами; місцеві центри розвитку різних видів спорту, спортивні свята тощо.

Зміст програми передбачає методологічні висновки - методичні рекомендації педагогам, алгоритм самоаналізу ефективності впровадження програми в окремо взятій школі. Наведемо деякі з них. Викладання предмета здійснюється в такій послідовності: від головних компетенцій до специфічних, до навчальної діяльності і після цього - до змісту. Учителі/викладачі закладів початкової освіти будуть проєктувати освітній процес залежно від особливостей класу, наявної матеріальної бази та бажання учнів.

3 метою визначення обізнаності 3 положеннями програми фахівцям фізичного виховання і вчителям початкових класів пропонувалося відповісти на такі питання.

- 3 якою метою я це зроблю (визначення компетенції)?

- Як це зроблю (визначення навчальних дій)?

- Які форми буду використовувати (вибір змісту)?

- Що буду робити (аналіз матеріальних ресурсів)?

- Скільки було реалізовано (визначення критеріїв для оцінювання)?

Відповідно до положень програми, гра стає методом, засобом і формою організації, здійсненої з/або без форми змагання, адаптованих до рухових і психічних можливостей учнів.
Завдяки рухливим діям дитина має змогу пізнавати, досліджувати, сприймати або не сприймати власний стан та емоції, взаємодіяти з власним тілом, іншими учасниками гри, 3 природним середовищем.

В обох класах акцентована робота в парах і групах, надана перевага інтеграції, допомозі та взаємному стимулюванню, розвитку спілкування й толерантності, вирішенню певних ситуацій дослідницького типу. Рекомендовано використання значної кількості інвентаря і реквізиту (м'ячі, кільця, прапорці, системи захисту тощо), які будуть захищати дітей, запобігатимуть нещасним випадкам. Рекомендовано, щоб засоби мали естетичний вигляд, були привабливими, легкими у пересуванні.

Для реалізації аналізованої ігрової програми повинні враховуватись такі аспекти:

- охоплення іграми і вправами всіх учнів, виходячи з їх індивідуальних особливостей;

- $\quad$ заборона ігор, у яких передбачено виведення з гри учнів;

- обов'язкове виконання ролі капітана кожним учасником;

- формування якісно рівних груп/команд;

- для можливості отримати реванш групі/команді, яка програла, будь-яке змагання треба повторювати мінімум три рази;

- нова гра обов'язково повторюється на 3-4 наступних уроках;

- ігри можуть повторюватися в нових варіаціях, враховуючи особливості учнів;

- планування уроків передбачає використання одної нової гри й одної 
засвоєної раніше; нової гри й одноїдвох естафет; двох ігор, засвоєних раніше; двох-трьох естафет;

- варто збалансовано поєднувати ігри й естафети під час одного уроку: швидкість - сила, спритність сила, спритність - витривалість;

- 3 метою оптимізації уроків необхідно формувати групи або команди з 6-8 учнів;

- рекомендовано використовувати щонайменше одну форму змагання на кожному уроці (індивідуальні, у парах, між групами, між командами вправи та ігри);

- упозашкільній діяльності варто використовувати рухливі ігри, які учні вивчили на уроках.

Як відомо, базовим елементом процесу навчання $є$ оцінювання його результатів, що реалізується шляхом поточного оцінювання (спостереження за поведінкою учня під час проведення ігор, за виконанням рухливих дій, дотриманням правил гри, використання навичок спілкування і праці в команді); етапне оцінювання (за семестр) буде враховувати ефективність участі учня не менш, ніж у чотирьох рухливих іграх, організованих упродовж семестру, з виконанням різних ролей. Крім того, буде враховуватись участь у позаурочній спортивно-масовій діяльності.

Висновки та перспективи подальших досліджень. Програма "Гра і рух" для 3 i 4 класу румунської школи, апробована згідно з додатком № 2 до наказу Міністра національної освіти Румунії № 5003/02.12.2014 в 2014 р. та впроваджена в навчальновиховну діяльність шкіл цієї країни у 2019 році. Відповідно до положень програми гра стає методом, засобом і формою організації, здійсненої з/ або без форми змагання, адаптованих до рухових і психічних можливостей учнів. Учень має змогу пізнавати, досліджувати, сприймати або не сприймати власний стан та емоції, взаємодіяти з власним тілом, іншими учасниками гри, природним середовищем.

Шкільна програма з курсу "Гра і рух" пропонує гнучке започаткування, основане на оцінці компетенцій i досвіді вчителя, специфічних ресурсах закладу освіти. Серед основних компетенцій програма називає: участь у рухливих іграх, організованих або спонтанних; демонстрація адекватної соціальної поведінки у щоденній діяльності.

Визначені умови реалізації аналізованої ігрової програми (урахування індивідуальних особливостей учнів, заборона ігор, у яких передбачено виведення з гри учнів; обов'язкове виконання ролі капітана кожним учасником; формування якісно рівних груп/команд тощо).

Надалі заплановано аналіз інших навчальних програм сфери "Фізична культура" румунських закладів освіти задля використання ефективних ідей в українській системі освіти.

\section{СПИСОК ЛІТЕРАТУРИ}

Гушлєвська, I. (2004). Поняття компетентності у вітчизняній та зарубіжній педагогіці. Шлях освіти, 3 , 22-24.

Legea nr. 69/2000, legea educatiei fizice si sportului, consolidata. (2009). Monitorul Oficial, I, 200, 2009.

Postolache, Nicolae. (2009). Fascinatia oinei jocul romanilor de pretutindeni. Editura Profexim, Bucuresti.

Programa scolara pentru disciplina "Educatie fizica?" clasele a III-a - a IVa. Anexa nr. 2 la ordinul ministrului educatiei nationale nr. 5003/02.12.2014. (2014) Ministerul educatiei nationale. Bucuresti.

Programa scolara pentru disciplina "Joc si miscare" clasele a III-a - a IV-a. Anexa nr. 2 la ordinul ministrului educatiei nationale nr. 5003/02.12.2014. (2014). Ministerul educatiei nationale. Bucuresti.

Tsybanyuk, O., Galan, Y., Yarmak, O., Kyselytsia, O., Paliichuk, Y., O. Moroz. (2018). Monitoring the physical condition of schoolchildren during the process of physical education. Journal of Physical Education and Sport, 2,
663-669.

Tsybanyuk, O., Galan, Y., Zavgorodnia, T., Strazhnikova, I., Kushnir, I., Shestobuz, O., Yarmak, O., Kozhokar, M. (2019). Correction of the psychophysiological state of young men aged 11-12 years by means of hiking tourism. Journal of Physical Education and Sport, 19, 2120-2126.

\section{REFERENCES}

Gushlevska, I. (2004). The concept of competence in domestic and foreign pedagogy. The path of education, 3 , 22-24. [in Ukrainian].

Law no. 69/2000, law on physical education and sports, consolidated. (2009). Official Gazette, I, 200. [in Romanian].

Postolache, Nicolae. (2009). The fascination of the sheep is the game of Romanians everywhere. Profexim Publishing House, Bucharest. [in Romanian].

The curriculum for the discipline "Physical education" grades III-IV. Annex no. 2 by order of the Minister of National Education no. 5003 / 12.02.2014. (2014). Ministry of National Education. Bucharest. [in Romanian].

The curriculum for the discipline "Game and movement" grades III-IV. Annex no. 2 by order of the Minister of National Education no. 5003 / 02.12.2014. (2014). Ministry of National Education. Bucharest. [in Romanian].

Tsybanyuk, O., Galan, Y., Yarmak,O., Kyselytsia, O., Paliichuk, Y., Moroz, O. (2018). Monitoring the physical condition of schoolchildren during the process of physical education. Journal of Physical Education and Sport, 2, 663-669.

Tsybanyuk, O., Galan, Y., Zavgorodnia, T., Strazhnikova, I., Kushnir, I., Shestobuz, O., Yarmak, O., Kozhokar, M. (2019). Correction of the psychophysiological state of young men aged 11-12 years by means of hiking tourism. Journal of Physical Education and Sport, 19, 2120-2126.

Стаття надійшла 2.04.2020 p. 